\title{
HTLV-II TAX Gene
}

National Cancer Institute

\section{Source}

National Cancer Institute. HTLV-II TAX Gene. NCI Thesaurus. Code C17368.

Tax gene of the HTLV-II virus. 